\title{
EKSTREMA TERMICZNE W GÓRACH ŚWIĘTOKRZYSKICH NA PRZEEOMIE XX I XXI WIEKU
}

\author{
Krzysztof Jarzyna
}

\section{Thermal extremes in the Swiętokrzyskie Mts (central Poland) at the turn of the $21^{\text {st }}$ century}

Abstract: The aim of this study was to determine the number of hot days, very hot days and very frosty days as well as heat waves and cold spells in the Świętokrzyskie Mts (central Poland) during the 1981-2013 period. Datasets of minimum and maximum daily air temperatures from the IMGW-PIB stations: Kielce-Suków, Bodzentyn and Święty Krzyż were used in the study. During the last 35 years 17 heat waves and 12 cold spells occurred in the study area. The number of hot and very hot days and heat waves on the summits of the Świętokrzyskie Mts (Święty Krzyż weather station) was 2-5 times lower than at the valley stations. There was an evident increase in the occurrence frequency of hot weather extremes in the 2001-2010 period as compared to the end of the past century. There is no clear tendency to change in the number of very frosty days and cold spells. Two indices: WSNC and WSNZ were proposed as tools for the assessment of the intensity of heat waves and cold spells.

Keywords: heat waves, cold spells, Świętokrzyskie Mts

Zarys treści: Celem pracy było określenie liczby dni gorących i upalnych, dni bardzo mroźnych oraz fal upałów i fal mrozów, które występowały w Górach Świętokrzyskich w okresie 1981-2013. Wykorzystano wartości temperatury maksymalnej i minimalnej z trzech stacji meteorologicznych IMGW-PIB: Kielce-Suków, Bodzentyn i Święty Krzyż. W ostatnim 35-leciu w obszarze badań wystąpiło 17 fal upałów i 12 fal mrozów. Liczba dni upalnych i fal upałów na wierzchowinach Gór Świętokrzyskich (stacja meteorologiczna Święty Krzyż) była 2-5 razy mniejsza niż w dolinach. Wyraźny jest też wzrost częstości 
ich występowania w dziesięcioleciu 2001-2010 w porównaniu z końcem poprzedniego stulecia. Nie stwierdzono tendencji zmian liczby dni bardzo mroźnych i fal mrozów w badanym wieloleciu. W pracy zaproponowano wskaźniki: WSNG i WSNZ jako narzędzia oceny intensywności fal upałów i fal mrozów.

Stowa kluczowe: fale upałów, fale mrozów, Góry Świętokrzyskie

\section{Wstęp}

Do ekstremów pogodowych często zagrażających zdrowiu i życiu ludzi należą fale upałów i fale mrozów. Ostatni raport IPCC (Hartmann i in. 2013) stwierdza wzrost częstości i intensywności fal upałów. Równocześnie - według autorów raportu wzrasta zakres zmienności temperatury powietrza. W następstwie tego silne mrozy i chłody, chociaż są rzadsze w Europie niż kilkadziesiąt lat temu, w dalszym ciągu pozostają częstymi zjawiskami pogodowymi. Przykładem tego jest atak zimy, który dotknął Wyspy Brytyjskie na przełomie 2009 i 2010 r. (Prior, Kendon 2011).

Zmiany częstości występowania, przestrzennego zasięgu, długości i nasilenia fal upałów uważane są za ważne wskaźniki obserwowanych zmian klimatu, czego wyrazem są liczne w ostatnich dziesięcioleciach prace opisujące m.in.: wieloletnią zmienność częstości ich występowania na pojedynczych stacjach meteorologicznych (np. Kyselý 2002; Tomczyk 2014), zasięg przestrzenny wybranych fal upałów (np. Rebetez i in. 2008; Twardosz, Kossowska-Cezak 2013), przyczyny występowania fal upałów (np. Black i in. 2004) czy wreszcie omawiające skutki występowania fal upałów (np. Huynen i in. 2001). Fale mrozów i fale chłodów rzadziej przyciągają zainteresowanie badaczy. Niemniej jednak każdy atak zimy w Europie Zachodniej był impulsem dla klimatologów do oceny jego wyjątkowości na tle wielolecia (np. Prior, Kendon 2011) oraz przyczyn jego występowania (np. Guirguis i in. 2011).

Jeśli jednak chcemy uzyskać pogląd na wielkość zagrożenia ze strony ekstremów termicznych, należy w analizie uwzględniać zarówno fale upałów, jak i fale mrozów. Zwłaszcza analiza przestrzennego zróżnicowania ich występowania w skali regionalnej i lokalnej ma duży walor praktyczny. Obok analizy zasięgu i przestrzennego zróżnicowania nasilenia fal upałów należy badać czasową zmienność ich występowania. Nieustanny bieg zjawisk pogodowych przynosi bowiem nowe ekstrema termiczne, takie jak niezwykle chłodny przełom stycznia i lutego 2012 r. czy epizody pogody upalnej latem 2012, 2013 i 2015 r., obserwowane w naszym kraju. W związku ze znaczeniem tych zjawisk jako wskaźników współczesnych zmian klimatu ważne jest, aby analiza powtarzalności fal upałówi fal mrozów była aktualna, a każda z tych fal została oceniona pod względem stopnia ich nasilenia gorąca czy chłodu na tle wielolecia. 
Celem niniejszego opracowania jest określenie częstości występowania dni gorących, dni upalnych, dni bardzo mroźnych oraz fal upałów i fal mrozów w Górach Świętokrzyskich w ostatnich dziesięcioleciach (1981-2013). W ograniczonym zakresie (dla danych z jednej z rozpatrywanych stacji meteorologicznych) odniesiono się też do fal upałów, które wystąpiły w 2015 r. Wykorzystanie w pracy danych z kilku stacji meteorologicznych pozwoliło określić nie tylko czasową zmienność występowania takich dni, ale również ich przestrzenne zróżnicowanie w obrębie regionu.

\section{Materiał i metoda}

Podstawowe dane pomiarowe wykorzystane w pracy to wartości temperatury maksymalnej $\left(\mathrm{t}_{\text {maks }}\right)$ i minimalnej $\left(\mathrm{t}_{\mathrm{min}}\right) \mathrm{z}$ trzech stacji meteorologicznych IMGW-PIB: Kielce-Suków, Bodzentyn i Święty Krzyż (ryc. 1). Sposób pomiarów temperatury powietrza na wszystkich trzech stacjach był taki sam. Ponadto w okresie 1981-2015 lokalizacja żadnej z nich nie uległa zmianie. Niewiele zmieniło się też w tym okresie ich otoczenie. Wykorzystane dane uznano więc z punktu widzenia pomiarówza jednorodne. Dane ze stacji meteorologicznej Kielce-Suków pozyskano z bazy Global Summary of the Day (GSOD), umieszczonej na serwerze NOAA (http://www. ncdc.noaa.gov, 15.06.2015). Dane ze stacji meteorologicznych w Bodzentynie i na Świętym Krzyżu pochodzą z archiwum Świętokrzyskiego Parku Narodowego.

Stacje meteorologiczne w Bodzentynie i w podkieleckim Sukowie reprezentują klimat obniżeń terenowych, podczas gdy stacja meteorologiczna Święty Krzyż zlokalizowana jest na wierzchowinie najwyższego w Górach Świętokrzyskich Pasma Łysogórskiego (ryc. 1). Różnica wysokości bezwzględnej pomiędzy najniżej (Kielce-Suków) i najwyżej (Święty Krzyż) położonym punktem pomiarowym wynosi $314 \mathrm{~m}$.

Przedmiotem analiz była liczba dni charakterystycznych termicznie - dni gorących $\left(\mathrm{t}_{\text {maks }_{\mathrm{s}}}>25,0^{\circ} \mathrm{C}\right)$, dni upalnych $\left(\mathrm{t}_{\text {maks }}>30,0^{\circ} \mathrm{C}\right)$, nocy gorą-

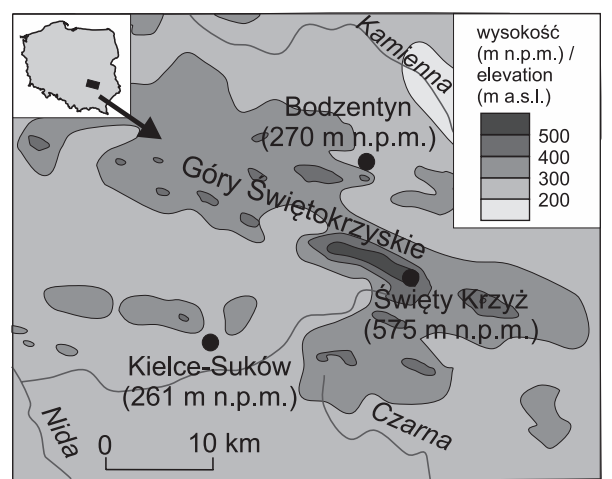

Ryc. 1. Obszar badań i położenie punktów pomiarowych

Fig. 1. Study area and location of measurement points

Źródto: opracowanie własne na podstawie Mapa przeglądowa Europy, Polska (1989).

Source: author's own work based on Mapa przeglądowa Europy, Polska (1989). 
cych, zwanych też nocami tropikalnymi $\left(\mathrm{t}_{\min }>20,0^{\circ} \mathrm{C}\right)$ oraz dni bardzo mroźnych $\left(\mathrm{t}_{\text {maks }}<-10,0^{\circ} \mathrm{C}\right)$. Określono ich średnią liczbę w kolejnych miesiącach zarówno dla całego okresu 1981-2013, jak i dla dziesięcioleci: 1981-1990, 1991-2000 i 2001-2010. Obliczone wartości średnie porównywano pomiędzy badanymi punktami oraz pomiędzy dziesięcioleciami. Istotność statystyczną różnic na poziomie istotności $\alpha<0,05$ określono testem $t$-Studenta.

Następnie wyróżniono fale upałów i fale mrozów. Definiowano je jako kilkudniowe okresy z temperaturą powietrza powyżej lub poniżej zadanych wartości progowych.

W Stowniku meteorologicænym (2003) falę upałów określono jako: „, kilkudniowy lub kilkutygodniowy okres, w którym temperatura maksymalna powietrza przekracza $30^{\circ} \mathrm{C}$, przedzielony krótkimi okresami chłodniejszymi". Polscy autorzy (m.in. Kuchcik 2006, Kossowska-Cezak 2010, Krzyżewska, Wereski 2011) przyjmują za Glossary of Mateorology (2015), że minimalny okres pogody upalnej pozwalający uznać go za falę upałów wynosi 3 dni. Podobnie i w niniejszym opracowaniu podstawą wyróżniania fal upałów uczyniono wystąpienie sekwencji przynajmniej 3 dni $\mathrm{z}$ temperaturą powyżej $30,0^{\circ} \mathrm{C}$.

Nie ma ogólnie przyjętej definicji fali mrozów. Korzystając z propozycji metodycznych stosowanych w innych pracach (m.in. Wibig i in. 2009a, Krzyżewska, Wereski 2011), wykorzystano dwa kryteria wyróżniania fal mrozów. Oba można uznać za ostre, wyróżniają bowiem niewiele takich okresów. Jedno opiera się na wartości temperatury maksymalnej, drugie zaś na wartości temperatury minimalnej. Fale mrozów wyróżniane na podstawie temperatury maksymalnej to okresy przynajmniej 3-dniowe z tą temperaturą poniżej-10,0C. Fale mrozów wyróżniane na podstawie temperatury minimalnej to okresy przynajmniej 3-dniowe $\mathrm{z}$ tą temperaturą poniżej $-20,0^{\circ} \mathrm{C}$.

Po wyróżnieniu fal mrozów i fal upałów określono ich liczbę na analizowanych stacjach dla całego okresu i poszczególnych dziesięcioleci. Określono również potencjalny okres występowania fal upałów i fal mrozów oraz okresy najczęstszego ich występowania. Obliczono również ich średnią i maksymalną długość. Im dłuższa fala upałów/mrozów, tym bardziej pogoda z nią związana jest uciążliwa. Uciążliwość fal upałów i fal mrozów zależy też od tego, jak bardzo temperatura powietrza odbiega od założonego progu. Zastosowano więc podejście podobne jak w przypadku obliczania sum temperatur efektywnych (Koźmiński, Michalska 1999). Dla każdej fali upałów zsumowano nadwyżki temperatury maksymalnej powyżej $30,0^{\circ} \mathrm{C}$ (wzorem metodyki z pracy Kyselý i in. 2000), a dla każdej fali mrozów zsumowano niedobory temperatury powietrza poniżej przyjętych wartości progowych temperatury maksymalnej lub minimalnej. W związku z tym, że sumy temperatur efektywnych znajdują zastosowanie niemal wyłącznie w pracach agroklimatycznych (np. Buczkowska, Bednarek 2005) w tym opracowaniu zaproponowano 
dla nich inną nazwę. Analizując fale upałów obliczano Wskaźnik Skumulowanego Nadmiaru Ciepła (WSNC), a przy charakteryzowaniu fal mrozów - Wskaźnik Skumulowanego Nadmiaru Zimna (WSNZ).

\section{Wyniki}

\section{Występowanie dni gorących i upalnych, nocy gorących oraz fal upałów w Górach Świętokrzyskich}

W okresie 1981-2013 na stacji meteorologicznej Kielce-Suków występowały średnio 38 dni gorące i 6 dni upalnych (tab. 1). Nieco rzadziej dni takie występowały na drugiej stacji położonej w dolinie - w Bodzentynie, odpowiednio: 34 oraz 4 dni. Dni takie najrzadziej występowały na znacznie wyżej położonej stacji meteorologicznej Święty Krzyż. Dni gorących było tam o połowę mniej (śr. 17 w roku), a dni upalne były bardzo rzadkie (śr. 0,8 w roku) - tab. 1. Różnice liczby dni gorących i upalnych pomiędzy stacją meteorologiczną Święty Krzyż i niżej położonymi punktami są istotne statystycznie na poziomie istotności 0,05. Różnice w liczbie tych dni pomiędzy Bodzentynem i podkieleckim Sukowem nie są istotne statystycznie.

Tab. 1. Przebieg roczny średniej liczby dni gorących $\left(\mathrm{t}_{\text {maks }}>25^{\circ} \mathrm{C}\right)$ i upalnych $\left(\mathrm{t}_{\text {maks }}>30^{\circ} \mathrm{C}\right)$ w Górach Świętokrzyskich w okresie 1981-2013

Table 1 . Annual course of hot $\left(\mathrm{t}_{\max }>25^{\circ} \mathrm{C}\right)$ and very hot $\left(\mathrm{t}_{\max }>30^{\circ} \mathrm{C}\right)$ days in the Świętokrzyskie Mts in the 1981-2013 period

\begin{tabular}{|c|c|c|c|c|c|c|c|c|c|c|c|c|c|c|}
\hline $\begin{array}{l}\text { Dni/ } \\
\text { days }\end{array}$ & $\begin{array}{l}\text { Stacje meteorolo- } \\
\text { giczne/ Weather } \\
\text { stations }\end{array}$ & 1 & II & III & IV & V & VI & VII & VIII & IX & $X$ & $X I$ & XII & $\begin{array}{l}\text { Rok/ } \\
\text { Year }\end{array}$ \\
\hline \multirow{3}{*}{ 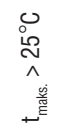 } & Kielce-Suków & . & $\cdot$ & . & 0,4 & 3,9 & 7,1 & 12,9 & 11,8 & 2,2 & 0,1 & . & . & 38,4 \\
\hline & Bodzentyn & . & & . & 0,2 & 2,6 & 6,2 & 12,1 & 10,8 & 1,8 & $0,0^{*}$ & . & . & 33,7 \\
\hline & Święty Krzyż & . & 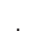 & . & 0,1 & 1,2 & 3,2 & 6,4 & 5,3 & 0,4 & . & . & . & 16,6 \\
\hline \multirow{3}{*}{ 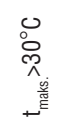 } & Kielce-Suków & . & . & . & . & 0,1 & 0,7 & 2,9 & 2,1 & 0,0 & . & . & . & 5,8 \\
\hline & Bodzentyn & . & . & . & . & 0,1 & 0,5 & 2,3 & 1,6 & . & . & . & . & 4,5 \\
\hline & Święty Krzyż & . & & . & . & . & 0,1 & 0,4 & 0,3 & . & . & . & 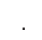 & 0,8 \\
\hline
\end{tabular}

Objaśnienia: * wartość 0,0 oznacza, średnia liczba dni gorących lub upalnych w danym miesiącu jest $<0,1$, co oznacza, że w całym okresie 1981-2013 wystąpił tylko 1 taki dzień.

Explanations: * 0.0 value means that the mean number of hot or very hot days in a given month is $<0.1$, i.e. only 1 such day occurred during the whole 1981-2013 period.

Źródto/Source: opracowanie własne/authors' own study. 
Dni gorące występowały w miesiącach od kwietnia do października, z maksimum w lipcu (tab. 1). Potencjalny okres ich występowania w Górach Świętokrzyskich wynosi 178 dni. W lipcu i sierpniu notowano co najmniej 10 dni gorących w położeniach dolinnych i ponad 5 dni gorących na wierzchowinie Łysogór (tab. 1).

Pierwsze dni gorące pojawiały się w kwietniu. Dotyczy to nawet Świętego Krzyża, gdzie 3 dni gorące wystąpiły pod koniec kwietnia 2012 r. W Kielcach-Sukowie najwcześniejszym dniem gorącym w badanym wieloleciu był 19 kwietnia 2000 r. W sumie dni gorące notowano tam w kwietniu aż w siedmiu latach (1993, 1996, 2000, 2003, 2010, 2012 i 2013). Najpóźniej dni gorące występowały w Górach Świętokrzyskich w październiku - w badanym 30-leciu jeden raz w Bodzentynie i trzykrotnie na stacji Kielce-Suków. Najpóźniejszym dniem gorącym na tej stacji meteorologicznej był 13 października 2000 r.

Okres występowania dni upalnych w Górach Świętokrzyskich jest krótszy. Jest on potencjalnie 112-dniowy, trwa od końca maja do połowy września (uwzględniając lato 2015 r.), z maksimum w lipcu. W lipcu i w sierpniu w Bodzentynie i podkieleckim Sukowie występowały średnio 2-3 dni upalne (tab. 1).

Liczba dni gorących i upalnych znacznie zmieniała się w kolejnych dziesięcioleciach (tab. 2). W dekadzie 2001-2010 średnia roczna liczba dni gorących była na rozpatrywanych stacjach meteorologicznych większa o 8-15 dni w porównaniu z dziesięcioleciem 1981-1990. Zmiany te były największe na stacji Kielce-Suków. Tam również wyraźnie zaznaczył się wzrost liczby dni upalnych w badanym wieloleciu; w latach 1981-1990 średnio w roku występowały trzy takie dni, w pierwszym

Tab. 2. Liczba dni gorących $\left(\mathrm{t}_{\text {maks. }}>25^{\circ} \mathrm{C}\right)$ i upalnych $\left(\mathrm{t}_{\text {maks }}>30^{\circ} \mathrm{C}\right)$ w Górach Świętokrzyskich w badanych dziesięcioleciach

Table 2. Number of hot $\left(\mathrm{t}_{\max }>25^{\circ} \mathrm{C}\right)$ and very hot $\left(\mathrm{t}_{\max }>30^{\circ} \mathrm{C}\right)$ days in the Świętokrzyskie Mts in the analyzed 10 -years periods

\begin{tabular}{|c|c|c|c|c|c|c|c|}
\hline \multirow{2}{*}{$\begin{array}{c}\text { Dni/ } \\
\text { Days }\end{array}$} & \multirow{2}{*}{$\begin{array}{l}\text { Okresy/ } \\
\text { Periods }\end{array}$} & \multicolumn{2}{|r|}{ Kielce-Suków } & \multicolumn{2}{|r|}{ Bodzentyn } & \multicolumn{2}{|r|}{ Święty Krzyż } \\
\hline & & śr. & min.-maks. & śr. & min.-maks. & śr. & min.-maks. \\
\hline \multirow{3}{*}{ 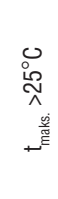 } & $\begin{array}{l}1981- \\
-1990\end{array}$ & 30,1 & $21(1990)-49(1983)$ & 29,1 & $\begin{array}{c}20(1984,1990)- \\
\quad-51(1983)\end{array}$ & 11,5 & $\begin{array}{c}8(1984,1987)- \\
-18(1982)\end{array}$ \\
\hline & $\begin{array}{l}1991- \\
-2000\end{array}$ & 35,8 & $23(1997)-55(1992)$ & 29,4 & $\begin{array}{l}16(1997)- \\
-55(1992)\end{array}$ & 14,7 & $4(1997)-26(1992)$ \\
\hline & $\begin{array}{l}2001- \\
-2010\end{array}$ & 45,6 & $30(2004)-60(2002)$ & 37,5 & $\begin{array}{c}19(2004)- \\
-48(2002,2007)\end{array}$ & 20,1 & $\begin{array}{c}10(2004,2008)- \\
-31(2002)\end{array}$ \\
\hline \multirow{3}{*}{ 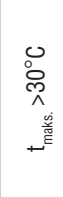 } & $\begin{array}{l}1981- \\
-1990\end{array}$ & 2,9 & $0(1990)-6(1988)$ & 2,5 & $\begin{array}{c}0(1981)- \\
-5(1986,1988)\end{array}$ & 0,0 & - \\
\hline & $\begin{array}{l}1991- \\
-2000 \\
\end{array}$ & 6,0 & $1(1997)-15(1994)$ & 5,0 & $\begin{array}{c}1 \text { (1996, 1997) - } \\
-15(1992) \\
\end{array}$ & 1,2 & 0 (7 lat/years)-6(1992) \\
\hline & $\begin{array}{l}2001- \\
-2010\end{array}$ & 7,5 & $2(2001)-22(2006)$ & 5,0 & $\begin{array}{c}1(2008)- \\
-11(2006,2010)\end{array}$ & 0,4 & $\begin{array}{c}0 \text { (8 lat/years)- } \\
-3(2007)\end{array}$ \\
\hline
\end{tabular}

Źródto/Source: opracowanie własne/authors' own study. 
dziesięcioleciu XXI w. było ich średnio osiem w roku. W Bodzentynie najmniej dni upalnych wystąpiło w dziesięcioleciu 1981-1990, na Świętym Krzyżu nie obserwowano ich wtedy w ogóle. W Bodzentynie w kolejnych dwóch dziesięcioleciach średnia roczna liczba dni upalnych nie zmieniała się, na wierzchowinie Łysogór było ich najwięcej w dziesięcioleciu 1991-2000 (tab. 2). Liczba dni gorących i upalnych w poszczególnych latach wyraźnie różniła się od wartości średnich dla dziesięcioleci i całego okresu. W roku 1997, odznaczającym się dżdżystym lipcem, na Świętym Krzyżu wystąpiły tylko cztery dni gorące, a w Kielcach 23 dni gorące i jeden dzień upalny. W całym 2002 r. dni gorących na Świętym Krzyżu było 31, a w Kielcach 60 (tab. 2). W roku 2015 w Kielcach wystąpiło najwięcej dni upalnych (27), począwszy od $1981 \mathrm{r}$.

Innym - obok dni upalnych - uciążliwym dla człowieka zjawiskiem jest występowanie nocy gorących. Inaczej niż w przypadku dni upalnych najwięcej zarejestrowano ich na stacji Święty Krzyż - 19 w całym badanym wieloleciu. W Bodzentynie było ich wówczas cztery, na stacji Kielce-Suków nie występowały w ogóle. Częstsze występowanie nocy gorących na Świętym Krzyżu w porównaniu z niżej położonymi stacjami meteorologicznymi jest nieco zaskakujące, ale daje się wytłumaczyć po uwzględnieniu wpływu lokalnych czynników klimatotwórczych. Zagadnienie to omówiono szczegółowo w dyskusji wyników.

Szczególnie uciążliwe dla ludzi jest występowanie dłuższych - co najmniej 3-dniowych - sekwencji dni upalnych, określanych jako fale upałów. Na stacjach meteorologicznych położonych w obniżeniach terenowych w całym okresie 1981-2013 wystąpiło kilkanaście fal upałów: 17 na stacji Kielce-Suków i 14 w Bodzentynie (tab. 3). Fale upałów trwały najdłużej w podkieleckim Suko-

Tab. 3. Fale upałów i najwyższe temperatury powietrza w Górach Świętokrzyskich w okresie 1981-2013

Table 3. Heat waves and the highest air temperature observed in the Świętokrzyskie Mts in the 1981-2013 period

\begin{tabular}{|c|c|c|c|c|c|c|}
\hline \multirow{3}{*}{$\begin{array}{c}\text { Stacje } \\
\text { meteorologiczne/ } \\
\text { Weather stations }\end{array}$} & \multicolumn{5}{|c|}{ Fale upałów/Heat waves } & \multirow{3}{*}{$\begin{array}{l}\text { Najwyższa temperatu- } \\
\text { ra powietrza/Highest } \\
\text { air temperature }\left({ }^{\circ} \mathrm{C}\right)\end{array}$} \\
\hline & \multirow{2}{*}{$\begin{array}{l}\text { liczba/ } \\
\text { number }\end{array}$} & \multicolumn{2}{|c|}{ długość (dni)/duration (days) } & \multicolumn{2}{|c|}{ WSNC $\left({ }^{\circ} \mathrm{C}\right)$} & \\
\hline & & śr./mean & maks. & śr./mean & maks. & \\
\hline Kielce-Suków & 17 & 4,5 & $\begin{array}{c}10 \\
(25.07-3.08 .1994 \\
20-29.07 .2006)\end{array}$ & $+10,7$ & $\begin{array}{c}+34,7 \\
(25.07 .-3.08 .1994)\end{array}$ & $36,4(8.08 .2013)$ \\
\hline Bodzentyn & 14 & 4,0 & $\begin{array}{c}9 \\
(25.07 .-2.08 .1994)\end{array}$ & $+8,4$ & $\begin{array}{c}+22,6 \\
(25.07 .-2.08 .1994)\end{array}$ & $36,2(29.07 .2013)$ \\
\hline Święty Krzyż & 3 & 3,3 & $\begin{array}{c}4 \\
(29.07 .-1.08 .1994)\end{array}$ & $+3,8$ & $\begin{array}{c}+5,3 \\
(15-17.07 .2007)\end{array}$ & $35,9(6.07 .2012)$ \\
\hline
\end{tabular}

Źródto/Source: opracowanie własne/authors' own study. 
wie - średnio 4,5 dnia. Na stacji tej stwierdzono również najwyższy skumulowany nadmiar ciepła (WSNC) - średnio $+10,7^{\circ} \mathrm{C}$. Najdłuższe w okresie 1981-2013 (10-dniowe) fale upałów występowały również na stacji meteorologicznej Kielce-Suków. Wystąpiło to dwukrotnie: w okresie 25 lipca -7 sierpnia 1994 r. i 20-29 lipca 2006 r. Pierwsza z tych fal upałów była bardziej uciążliwa, jej wskaźnik skumulowanego nadmiaru ciepła wynosił aż $+34,7^{\circ} \mathrm{C}$. W Bodzentynie fala upałów z przełomu lipca i sierpnia 1994 roku trwała dziewięć dni, a jej skumulowany nadmiar ciepła wynosił $+22,6^{\circ} \mathrm{C}$. Na najwyżej położonej stacji meteorologicznej Święty Krzyż wystąpiły tylko trzy krótkie fale upałów. Najbardziej uciążliwa wystąpiła w dniach 15-17 lipca 2007 r. (tab. 3). Najmniej fal upałów wystąpiło w latach 1981-1990 - na stacji meteorologicznej Kielce-Suków 2, a w Bodzentynie jedna. W Bodzentynie najwięcej fal upałów było w latach 1991-2000, a w Sukowie w latach 2001-2010 (ryc. 2A). Już po zakończeniu analizowanego w pracy wielolecia 1981-2013, latem 2015 r. na stacji meteorologicznej w Kielcach-Sukowie wystąpiły aż trzy fale upałów. Jedna z nich (ta z pierwszej połowy sierpnia 2015 r.)
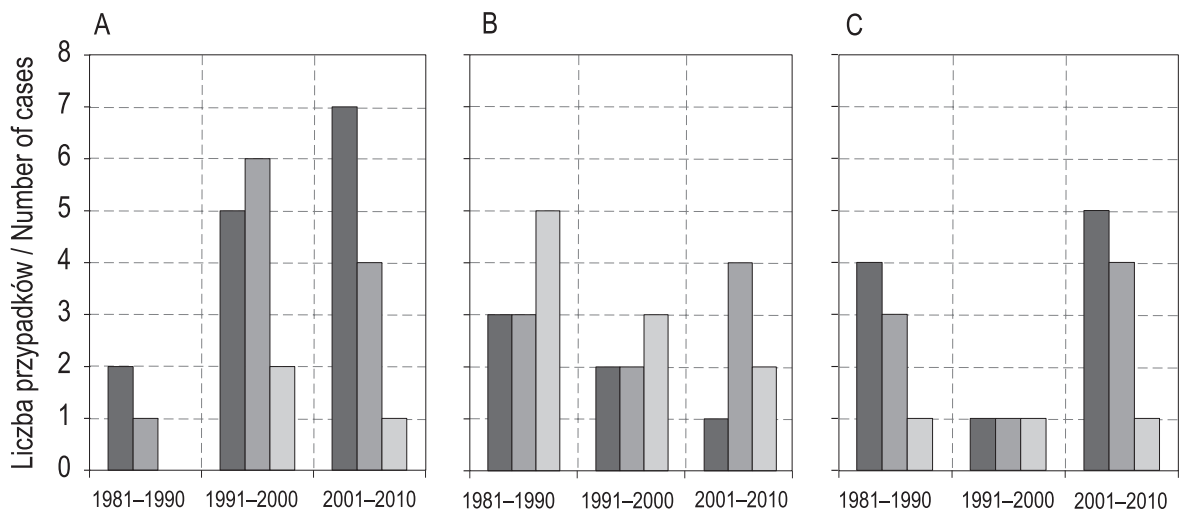

Dziesięciolecia / 10-years periods

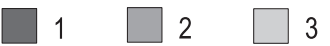

Ryc. 2. Liczba fal upałów (A) i fal mrozów wydzielanych na podstawie 2 kryteriów: co najmniej 3 dni $\mathrm{z} \mathrm{t}_{\text {maks. }}<-10^{\circ} \mathrm{C}(\mathrm{B})$, co najmniej $3 \mathrm{dni} \mathrm{z}_{\text {min. }}<-20^{\circ} \mathrm{C}(\mathrm{C}) \mathrm{w}$ badanych dziesięcioleciach

Fig. 2. Number of heat waves (A) and cold spells determined using 2 criteria: at least 3 days with $\mathrm{t}_{\max }<-10^{\circ} \mathrm{C}(\mathrm{B})$, at least 3 days with $\mathrm{t}_{\min }<-10^{\circ} \mathrm{C}(\mathrm{B})$ in the analyzed 10 -years periods ObjaśnienialExplanations: 1 - Kielce-Suków, 2 - Bodzentyn, 3 - Święty Krzyż.

Źródto/Source: opracowanie własne/authors' own study. 
była wyjątkowo uciążliwa - trwała $11 \mathrm{dni}$, a jej WSNC wynosił $+33,1^{\circ} \mathrm{C}$. Jej uciążliwość była więc porównywalna z falą upałów z 1994 r. W pierwszych pięciu latach obecnej dekady na stacji meteorologicznej Kielce-Suków wystąpiło sześć fal upałów - niewiele mniej niż w dziesięcioleciu 2001-2010.

Okres potencjalnego występowania fal upałów jest w Górach Świętokrzyskich krótszy od okresu występowania dni upalnych, wynosi 82 dni. Najwcześniejsza z nich wystąpiła w Górach Świętokrzyskich na przełomie pierwszej i drugiej dekady czerwca, najpóźniejsza na przełomie sierpnia i września Najczęściej fale upałów pojawiały się na przełomie lipca i sierpnia (ryc. 3).

Najwyższe w badanym okresie temperatury maksymalne wystąpiły w Górach Świętokrzyskich w ostatnich latach. Na stacji Kielce-Suków była to temperatura powietrza 36, $4^{\circ} \mathrm{C}$ w dniu 8 sierpnia 2013 r. Latem 2013 r. rekordowo wysoką dobową temperaturę powietrza zarejestrowano również w Bodzentynie. Na Świętym Krzyżu rekordowo ciepły był 6 lipca 2012 r.; zarejestrowano wówczas temperaturę 35,9 C (tab. 3 ).

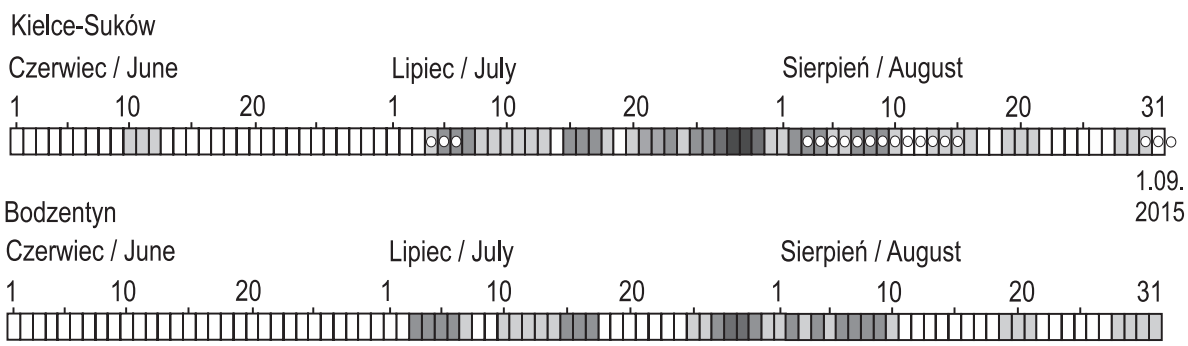

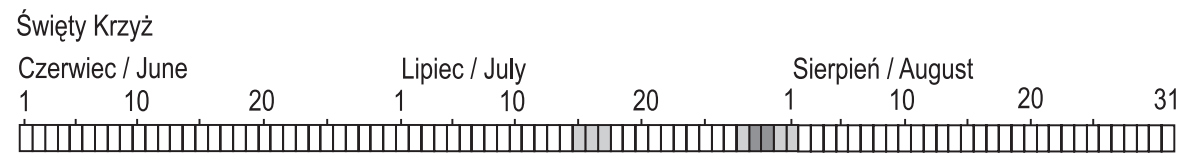

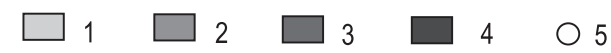

Ryc. 3. Powtarzalność fal upałów w Górach Świętokrzyskich w latach 1981-2013 (2015)

Fig. 3. Recurrence of heat waves in the Świętokrzyskie Mts during the 1981-2013 (2015) period

Objaśnienia: 1-4 - liczba przypadków wystąpienia fal upałów w danym dniu w roku, 5 - fale upałów w 2015 r. (dane tylko ze stacji meteorologicznej Kielce-Suków).

Explanations: 1-4-number of cases of the occurrence of heat waves on a given day of the year, 5-2015 heat waves (data only for the Kielce-Suków weather station).

Źródto/Source: opracowanie własne/authors' own study. 


\section{Występowanie dni bardzo mroźnych i fal mrozów w Górach Świętokrzyskich}

W okresie 1981-2013 na stacjach meteorologicznych Kielce-Suków i Bodzentyn występowały średnio dwa dni bardzo mroźne rocznie (tab. 4). Nieco częściej dni takie występowały na najwyżej położonej stacji meteorologicznej Święty Krzyż średnio trzy dni w roku. Różnica ta nie jest istotna statystycznie na poziomie 0,05 .

Dni bardzo mroźne występowały w Górach Świętokrzyskich w miesiącach od końca listopada do początku marca, z maksimum w styczniu (tab. 4). W miesiącu tym na stacji meteorologicznej Kielce-Suków występowało średnio 0,8 dni bardzo mroźnych, na stacji w Bodzentynie jeden dzień bardzo mroźny, a na Świętym Krzyżu średnio dwa dni bardzo mroźne (tab. 4). Na Świętym Krzyżu okres występowania dni bardzo mroźnych był najdłuższy i wynosił 106 dni. W okresie 1981-2013 najwcześniejszy dzień bardzo mroźny wystąpił tam 22 listopada 1998 r., a najpóźniejszy 7 marca 1987 r.

W Bodzentynie średnia liczba dni bardzo mroźnych była podobna we wszystkich analizowanych dziesięcioleciach (tab. 5). Na stacji meteorologicznej Kielce-Suków liczba dni bardzo mroźnych stopniowo się zmniejszała - w dziesięcioleciu 2001-2010 była ponad dwa razy mniejsza niż w dziesięcioleciu 1981-1990. $\mathrm{Na}$ Świętym Krzyżu wyraźny spadek liczby dni bardzo mroźnych nastąpił dopiero w dziesięcioleciu 2001-2010 (tab. 5). Dni bardzo mroźne nie występowały we wszystkich latach badanego okresu. Najwięcej stwierdzono ich w roku 1985

Tab. 4. Przebieg roczny średniej liczby dni bardzo mroźnych $\left(\mathrm{t}_{\text {maks. }}<-10^{\circ} \mathrm{C}\right)$ w Górach Świętokrzyskich w okresie 1981-2013

Table 4. Annual course of very frosty days $\left(\mathrm{t}_{\max }<-10^{\circ} \mathrm{C}\right)$ in the Świętokrzyskie Mts in the 1981-2013 period

\begin{tabular}{|c|c|c|c|c|c|c|c|c|c|c|c|c|c|c|}
\hline $\begin{array}{l}\text { Dni// } \\
\text { Days }\end{array}$ & $\begin{array}{c}\text { Stacje } \\
\text { meteorologiczne/ } \\
\text { Weather stations }\end{array}$ & I & II & III & IV & V & VI & VII & VIII & IX & $x$ & $\mathrm{XI}$ & XII & Rok \\
\hline \multirow{3}{*}{ 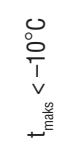 } & Kielce-Suków & 0,9 & 0,5 & $0,0^{*}$ & . & & & . & . & . & . & . & 0,4 & 1,8 \\
\hline & Bodzentyn & 1,2 & 0,5 & 0,0 & . & & & & . & & & . & 0,4 & 2,1 \\
\hline & Święty Krzyż & 1,6 & 1,1 & 0,1 & . & . & . & . & . & . & . & 0,0 & 0,5 & 3,3 \\
\hline
\end{tabular}

Objaśnienia: * wartość 0,0 oznacza, średnia liczba dni bardzo mroźnych w danym miesiącu jest $<0,1$, co oznacza, że w całym okresie 1981-2013 wystąpił tylko 1 taki dzień 0,0.

Explanations: * 0.0 value means that the mean number of very frosty days in a given month is $<0.1$, i.e. only 1 such day occurred during the whole 1981-2013 period.

Źródto/Source: opracowanie własne/authors' own study. 
Tab. 5. Liczba dni bardzo mroźnych $\left(\mathrm{t}_{\text {maks. }}<-10^{\circ} \mathrm{C}\right)$ w Górach Świętokrzyskich w badanych dziesięcioleciach

Table 5. Number of very frosty days $\left(\mathrm{t}_{\max }<-10^{\circ} \mathrm{C}\right)$ in the Świętokrzyskie Mts in the analyzed 10 -years periods

\begin{tabular}{|c|c|c|c|c|c|c|c|}
\hline \multirow{2}{*}{$\begin{array}{l}\text { Dni/ } \\
\text { Days }\end{array}$} & \multirow{2}{*}{$\begin{array}{l}\text { Okresy/ } \\
\text { Periods }\end{array}$} & \multicolumn{2}{|r|}{ Kielce-Suków } & \multicolumn{2}{|r|}{ Bodzentyn } & \multicolumn{2}{|r|}{ Święty Krzyż } \\
\hline & & $\begin{array}{l}\text { śr./ } \\
\text { mean }\end{array}$ & min.-maks. & $\begin{array}{l}\text { śr./ } \\
\text { mean }\end{array}$ & min.-maks. & $\begin{array}{c}\text { śr.l } \\
\text { mean }\end{array}$ & min.-maks. \\
\hline \multirow{3}{*}{ 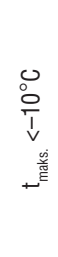 } & $\begin{array}{l}1981- \\
-1990\end{array}$ & 2,5 & $\begin{array}{c}0(1981-1984 \\
1988-990)-12(1985)\end{array}$ & 2,3 & $\begin{array}{c}0(1981-1984 \\
1988-1990)-11(1987)\end{array}$ & 3,7 & $\begin{array}{c}0(1984, \\
1988-1990)- \\
-15(1985)\end{array}$ \\
\hline & $\begin{array}{l}1991- \\
-2000 \\
\end{array}$ & 1,9 & $\begin{array}{c}0(1992,1994,1995, \\
1998,2000)-10(1996)\end{array}$ & 2,1 & $\begin{array}{c}0(1992,1998-2000)- \\
-10(1996)\end{array}$ & 3,2 & $0(2000)-15(1996)$ \\
\hline & $\begin{array}{l}2001- \\
-2010\end{array}$ & 1,1 & $\begin{array}{c}0(2001,2004,2005 \\
2007,2008)- \\
-3(2009,2010)\end{array}$ & 2,1 & $\begin{array}{c}0(2001,2005,2007 \\
2008)-5(2010)\end{array}$ & 2,2 & $\begin{array}{c}0(2001,2005, \\
2007,2008)-8 \\
(2010)\end{array}$ \\
\hline
\end{tabular}

Źródto/Source: opracowanie własne/authors' own study.

(15 na stacji Święty Krzyż i 12 dni w Kielcach-Sukowie), 1987 (11 dni bardzo mroźnych w Bodzentynie) i w 1996 r. (15 na stacji Święty Krzyż) (tab. 5).

Co najmniej 3-dniowe spadki temperatury powietrza poniżej założonych wartości progowych wyróżniono jako fale mrozów. Ich liczba na badanych stacjach meteorologicznych różni się jednak w zależności od przyjętego kryterium wydzielania (tab. 6). Jeśli podstawą wydzielania fal mrozów uczynimy występowanie dni bardzo mroźnych $-\mathrm{z}$ temperaturą maksymalną $<-10,0^{\circ} \mathrm{C}$, wówczas tak zdefiniowane fale mrozów najczęściej występowały na stacji meteorologicznej Święty Krzyż (12 przypadków), najrzadziej na stacji Kielce-Suków ( 7 przypadków). Jeśli wydzielając fale mrozów wykorzysta się temperaturę minimalną, zakładając jej wartość progową na poziomie $-20,0^{\circ} \mathrm{C}$, wówczas na Świętym Krzyżu wydzielimy w okresie 1981-2013 tylko cztery fale mrozów, a na stacji meteorologicznej Kielce-Suków aż 10 fal mrozów (tab. 6). Średnia długość fali mrozów zawiera się w przedziale od 3,9 do 5,5 dni. Najdłuższa na stacjach dolinnych fala mrozów trwała w zależności od przyjętego kryterium od 6 do 9 dni. Wystąpiła ona w połowie stycznia 1987 r. Na stacji Kielce-Suków, przy zastosowaniu kryterium temperatury maksymalnej, równie długa jak w 1987 roku była fala mrozów z przełomu grudnia 1996 r. i stycznia 1997 r. Na Świętym Krzyżu najdłuższą falą mrozów wyróżnioną za pomocą kryterium uwzględniającego maksymalną temperaturę był 16-dniowy okres silnych mrozów na przełomie stycznia i lutego 2012 r. Również wskaźnik skumulowanego nadmiaru zimna (WSNZ) największy był w trakcie fali mrozów z 1987 r. (na stacjach: Kielce-Suków i Bodzentyn) i w trakcie fali mrozów z 2012 r. (na Świętym Krzyżu) - tab. 6. 


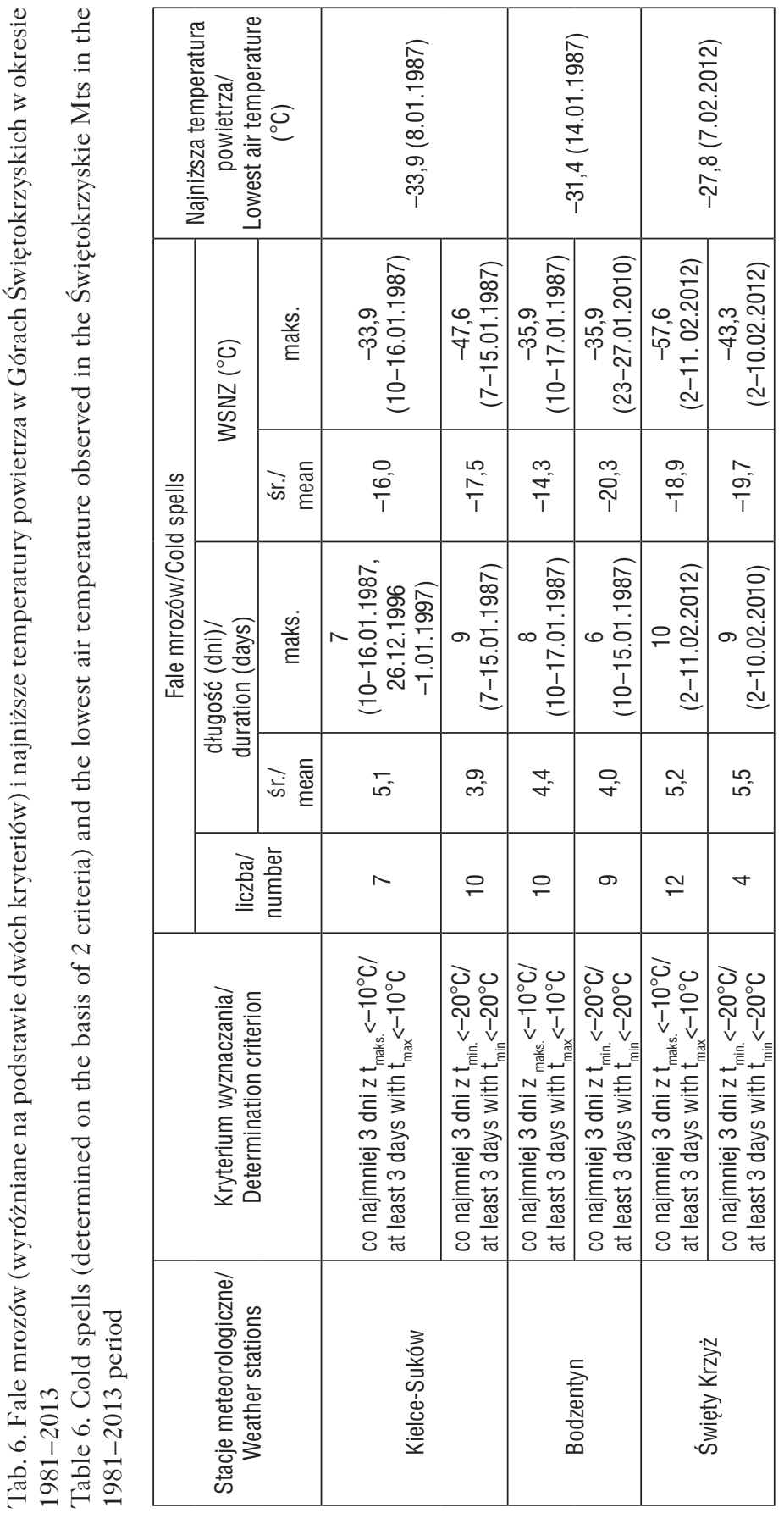




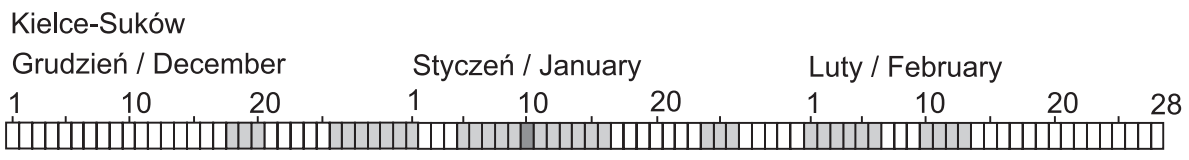

Bodzentyn
Grudzień / December
1

\section{Święty Krzyż}

Grudzień / December Styczeń / January Luty / February

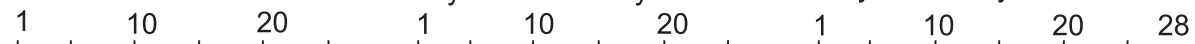

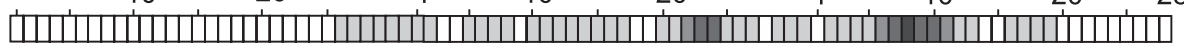

\section{$1 \square 2 \square 3 \square 4$}

Ryc. 4. Powtarzalność fal mrozów (co najmniej 3 dni z $\mathrm{t}_{\text {maks. }}<-10^{\circ} \mathrm{C}$ ) w Górach Świętokrzyskich w latach 1981-2013

Fig. 4. Recurrence of cold spells (at least 3 days with $t_{\max }<-10^{\circ} \mathrm{C}$ ) in the Świętokrzyskie Mts during the 1981-2013 period

Objaśnienia: 1-4 - liczba przypadków wystąpienia fal mrozów w danym dniu w roku.

Explanations: 1-4-number of cases of the occurrence of cold spells on a given day of the year.

Źródto/Source: opracowanie własne/authors' own study.

Na stacjach dolinnych liczba fal mrozów wyróżnionych z pomocą opisanych kryteriów była mniejsza niż liczba fal upałów. W czasie fal mrozów temperatura powietrza spadała jednak znacznie niżej od przyjętych wartości progowych w porównaniu ze wzrostem temperatury powietrza powyżej wartości progowej dla fal upałów. Na podstawie uzyskanych wyników nie da się jednoznacznie stwierdzić, że liczba fal mrozów w wieloleciu 1981-2013 wykazywała tendencję malejącą (ryc. 2B, 2C).

Najwcześniej fale mrozów, wyróżnione na podstawie kryterium temperatury maksymalnej, występowały na uwzględnionych stacjach pod koniec drugiej dekady grudnia, najpóźniej zaś pod koniec drugiej dekady lutego. Potencjalny okres ich występowania wynosił 63 dni. Częściej niż raz w całym badanym wieloleciu fale mrozów pojawiły się w pierwszej i trzeciej dekadzie stycznia, a na Świętym Krzyżu również w pierwszej dekadzie lutego (ryc. 4).

Na stacjach meteorologicznych Kielce-Suków i Bodzentyn najniższa w badanym wieloleciu temperatura powietrza wystąpiła w pierwszym dziesięcioleciu badanego okresu - w styczniu 1987 r. W Kielcach-Sukowie było to $-33,9^{\circ} \mathrm{C}$ w dniu 8 stycznia 
1987 r., w Bodzentynie zaś -31,4 C w dniu 14 stycznia 1987 r. Na Świętym Krzyżu w tym miesiącu również obserwowano silne mrozy, ale najniższa w badanym okresie temperatura minimalna wystąpiła tam niedawno, w dniu 7 lutego 2012 r. i wyniosła $-27,8^{\circ} \mathrm{C}$ ( tab. 6).

\section{Dyskusja}

Proponowane w literaturze kryteria wydzielania fal upałów i fal mrozów są zróżnicowane. Ich przegląd można znaleźć w pracy Krzyżewskiej (2014).

W szeregu prac w odniesieniu do fal upałów powtarza się wartość progowa temperatury maksymalnej równa $30,0^{\circ} \mathrm{C}$ i minimalny czas jej występowania równy trzy dni (np. Kuchcik 2006; Kossowska-Cezak 2010). Takie same kryteria zastosowano również w niniejszej pracy. Inne kryteria zastosowała Panfil (2005). Wyróżniane przez tę autorkę fale upałów to sekwencje co najmniej czterech dni z temperaturą maksymalną przekraczającą $25,0^{\circ} \mathrm{C}$. Stosując wspomniane kryteria, wydzieliła ona w północno-wschodniej Polsce w dziesięcioleciu 1991-2000 aż 27 fal upałów, znacznie więcej niż wydzielono ich w Górach Świętokrzyskich w niniejszej pracy w całym okresie 1981-2013. Co więcej, zastosowanie przez Panfil mniej ostrych kryteriów wydzielania fal upałów spowodowało, że stwierdzała ich występowanie nie tylko w miesiącach letnich, ale również w maju, wrześniu, a nawet w kwietniu.

Jeszcze inaczej do rozwiązania problemu wydzielania fal upałów podszedł zespół pod kierunkiem Wibig (2009b). Zamiast przyjąć sztywny minimalny czas występowania warunków kryterialnych badacze określali, jak często występowały fale upałów o różnym czasie trwania. Pojedynczy dzień upalny nazywali oni również falą upałów (zob. tab. 2 w tejże pracy), co nie wydaje się właściwe.

Nie ma powszechnie przyjmowanych kryteriów wydzielania fal mrozów (ewentualnie fal chłodów). W Stowniku meteorologicænym (2003) brak takiego hasła. W Słowniku Amerykańskiego Towarzystwa Meteorologicznego można znaleźć pojęcie cold wave, czyli gwałtowny spadek temperatury powietrza poniżej wartości zagrażających zdrowiu i gospodarczej działalności człowieka (Glossary of Meteorology 2015). Definicja ta nie precyzuje ani wartości progowej temperatury powietrza, poniżej której musi ona spaść, ani czasu trwania takich warunków, kładąc nacisk na gwałtowność tego spadku. W szeregu prac naukowych pojawia się pojęcie cold spell („okres chłodów”), definiowane podobnie do analizowanych w pracy fal mrozów, czyli jako kilkudniowy spadek temperatury powietrza poniżej założonej wartości progowej. Huynen i współpracownicy (2001), analizując wpływ występowania okresów chłodów na umieralność mieszkańców Holandii, zdefiniowali okresy chłodów jako okresy przynajmniej 9-dniowe z temperaturą minimalną spadającą poniżej $-5,0^{\circ} \mathrm{C}$ ( w tym 6 dni z temperaturą poniżej $-10,0^{\circ} \mathrm{C}$ ). Kyselý z zespołem 
(2009) jako okresy chłodów traktowali co najmniej trzy kolejne dni z temperaturą maksymalną niższą niż $-3,5^{\circ} \mathrm{C}$. Powyższe kryteria różnią się od przyjętych w niniejszej pracy. Są one łagodniejsze, chociaż w oceanicznym klimacie Holandii pozwoliły wyróżnić w okresie 1979-1997 tylko pięć okresów chłodów (Huynen i in. 2001). Zarówno Panfil (2005), jak i Krzyżewska i Wereski (2011) zastosowali w wydzielaniu fal mrozów wartość progową temperatury powietrza równą $-10,0^{\circ} \mathrm{C}$. Uzyskane w tych pracach wyniki znacznie się jednak różniły, gdyż Panfil posłużyła się wartościami temperatury minimalnej, a Krzyżewska i Wereski wartościami temperatury maksymalnej. W pierwszej ze wspomnianych prac wyróżniono w Polsce Północno-Wschodniej w okresie 1991-2000 ponad 15 fal mrozów, w drugiej zaś w okresie 2000-2010 wyróżniono na stacjach meteorologicznych tego samego regionu Polski tylko 3-4 fale mrozów.

Stwierdzone w Kielcach ekstrema termiczne $\left(-33,9^{\circ} \mathrm{C}\right.$ i $\left.36,4^{\circ} \mathrm{C}\right)$ są rekordowe nie tylko w wieloleciu 1981-2015, ale w całym okresie pomiarów od 1951 r. (za: Woś 2010).

W pracy określono też, korzystając z metodyki zaproponowanej przez Kyselýego i in. (2000) Wskaźnik Skumulowanego Nadmiaru Ciepła i analogiczny do niego Wskaźnik Skumulowanego Nadmiaru Zimna. Są one dobrą miarą nasilenia fal upałów i fal mrozów, gdyż ich wartość wynika zarówno z długości tych fal, jak i wielkości przekroczenia kryterialnych wartości temperatury powietrza. Wspomniane wskaźniki nadają się do porównań regionalnych i lokalnych. Wskaźnik Skumulowanego Nadmiaru Ciepła fal upałów, które latem 1994 r. wystąpiły na Morawach, wyniósł w Brnie $+67,2^{\circ} \mathrm{C}$ ( Kyselý i in. 2000 ), podczas gdy podobny wskaźnik obliczony dla fali upałów, która wystąpiła wówczas w Kielcach, wyniósł tylko $+34,7^{\circ} \mathrm{C}$. W trakcie fali upałów w sierpniu 2013 r. WSNC wynosił w podkieleckim Sukowie i w centrum miasta odpowiednio: $+16,6^{\circ} \mathrm{C}$ oraz $+20,3^{\circ} \mathrm{C}$, wskazując na większe obciążenie cieplne organizmu człowieka w centrum miasta. Innym wskaźnikiem nasilenia fal upałów jest średnia temperatura maksymalna podczas trwania danej fali upałów (Batko, Twardosz 2013). Stosując ten wskaźnik, autorzy wspomnianej pracy stwierdzili, że największe nasilenie miały krótkotrwałe fale upałów (3-4-dniowe).

W okresie 2000-2010 stacja meteorologiczna w Kielcach nie wyróżniała się według Krzyżewskiej i Wereskiego (2011) - na tle stacji niżej leżących większą liczbą fal mrozów. Fale upałów były tam nieco rzadsze niż w np. w: Warszawie czy Rzeszowie, ale z podobną częstością pojawiały się w wielu innych regionach Polski.

Tym bardziej warto podkreślić zróżnicowanie częstości występowania dni i okresów ekstremalnych termicznie w obrębie regionu świętokrzyskiego. Dotyczy to przede wszystkim różnic pomiędzy stacjami położonymi w obniżeniach (Bodzentyn i Kielce-Suków) a położoną ponad 300 m wyżej stacją Święty Krzyż. Na wierzchowinie Łysogór występowało kilka razy mniej dni gorących i upalnych oraz fal upałów niż na pozostałych stacjach. Najczęstsze były tam za to dni bardzo mroźne i fale mrozów wyróżniane z wykorzystaniem wartości temperatury 
maksymalnej. Nieco zaskakiwać może jednak to, że właśnie na Świętym Krzyżu występowało najwięcej nocy gorących oraz najmniej fal mrozów wyróżnianych z wykorzystaniem progowej wartości temperatury minimalnej. Wiązać to należy z tym, że w nocy spadek temperatury w obrębie wklęsłych form rzeźby jest silniejszy niż na stokach i wierzchowinie form wypukłych. Skutkiem tego w nocy i rano często występują względne inwersje termiczne - z niższą temperaturą powietrza w dolinach w porównaniu z wierzchowinami pasm Gór Swiętokrzyskich (Niedźwiedź i in. 1973; Kłysik 1974).

Należy też pamiętać o tym, że Góry Świętokrzyskie to góry niskie. W rezultacie na ich szczytach występują zarówno dni gorące, jak i upalne. W górach wyższych dni takie mogą w ogóle nie występować, jak np. na Śnieżce w Karkonoszach (Głowicki 2008). Wzrasta tam również liczba dni bardzo mroźnych. Na Śnieżce były one w okresie 1951-2007 ponad 10 razy liczniejsze niż na położonej u podnóża Karkonoszy stacji meteorologicznej w Jeleniej Górze. Na Świętym Krzyżu średnio dni bardzo mroźnych było tylko ok. 1,5 razy więcej niż w leżącym u podnóża Łysogór Bodzentynie.

Analiza zmian liczby dni charakterystycznych oraz fal upałów i fal mrozów w badanych dziesięcioleciach do pewnego stopnia potwierdza przedstawione na wstępie wnioski autorów ostatniego raportu IPCC (Hartmann i in. 2013). O ile wyraźnie wzrosła liczba dni gorących i upalnych w ostatnich dziesięcioleciach (zwłaszcza na stacji meteorologicznej Kielce-Suków), o tyle spadek liczby dni bardzo mroźnych jest mniej wyraźny, ale zauważalny (poza Bodzentynem). Stąd obok coraz częstszych fal upałów w dalszym ciągu pojawiają się i w najbliższym okresie pojawiać się będą fale mrozów. Ostatnia niezwykle uciążliwa fala mrozów wystąpiła na przełomie stycznia i lutego 2012 r. Fale upałów nie występowały niemalże w latach 80 . XX w. W ostatnich 10 latach pojawiają się one w niższych położeniach w Górach Świętokrzyskich raz na 2-3 lata. W niektórych latach (1992, 2006, 2010, 2013, 2015) wystąpiło kilka fal upałów.

Kossowska-Cezak (2010) przeanalizowała zmienność występowania fal upałów w Warszawie w znacznie dłuższym okresie: 1951-2009. W okresie 1951-1990 zarejestrowała ona 12 fal upałów, a w dwa razy krótszym okresie 1991-2009 wystąpiło ich aż 17. Podobne wnioski w odniesieniu do zmienności występowania dni gorących i upalnych w kotlinach sudeckich i na Przedgórzu Sudeckim przedstawia Głowicki (2008). Wyraźny wzrost liczby tych dni zaznacza się w latach 1991-2007. Nie wszystkie studia wieloletnich zmian liczby fal upałów potwierdzają jednak tę tendencję. W Lublinie w okresie 1951-1980 wystąpiło 18 fal upałów, a późniejszym okresie 1991-2010 tylko 12 fal upałów (Krzyżewska 2015).

Z kolei przeciętna liczba dni bardzo mroźnych w Sudetach i na Przedgórzu Sudeckim największa była w latach 1960., najmniejsza zaś w okresie 2001-2007 (Głowicki 2008). 
Niektóre serie pomiarów temperatury powietrza pozwalają analizować zmienność liczby fal upałów i fal mrozów w jeszcze dłuższych okresach. Analiza prawie 100-letniej serii pomiarów z Pragi (Kyselý 2002) wskazała w XX w. dwa okresy częstego występowanie fal upałów - przełom lat 1940. i 1950. oraz połowę lat 1990., kiedy w 1994 r. wystąpiła najbardziej uciążliwa fala upałów.

Jeszcze dalej w przeszłość sięga Piotrowicz (2005), analizując występowanie ciągów dni upalnych i bardzo mroźnych w Krakowie w okresie 1826-2003. Najdłuższym (17-dniowym) ciągiem dni upalnych był wspomniany już okres upalny z przełomu lipca i sierpnia 1994 r. Kolejne pod względem długości okresy wystąpiły jednak w latach 30. i 40. XIX w. W XIX w. zarejestrowano też najdłuższe ciągi dni bardzo mroźnych, chociaż wśród 12 najdłuższych ciągów takich dni autorka wymienia też ten z zimy 1995/1996.

Okres częstego występowania ekstremów termicznych w wieku XIX pokrywa się ze schyłkiem małej epoki lodowej, której ważną cechą była duża zmienność warunków pogodowych w kolejnych latach (Mann 2002). Potwierdzają to wyniki rekonstrukcji klimatu Europy Środkowej od XVI w. (Dobrovolný i in. 2011). Wskazują one, że zmienność temperatury w zimie i lecie, wyrażona odchyleniem standardowym była w pierwszej połowie XIX w. większa niż w późniejszym okresie. Współcześnie również obserwujemy wzrost zakresu zmienności temperatury minimalnej i maksymalnej w porównaniu z połową XX w. (Hartmann i n. 2013).

Zacytowane wyżej wyniki badań sugerują, że liczba fal upałów i fal mrozów w dłuższym okresie zmieniała się oscylacyjnie. Obserwowany wzrost częstości anomalii termicznych może więc być odzwierciedleniem zarówno globalnych trendów klimatycznych, jak i zmienności o charakterze oscylacyjnym, wywołanej np. międzydekadowymi zmianami cyrkulacji atmosferycznej. Sytuacjami cyrkulacyjnymi sprzyjającymi falom upałów i falom mrozów są wyże blokujące (np. Black i in. 2004; Sillmann, Croci-Maspioli 2009; Bielec-Bąkowska 2014). Zmiany reżimu i regionów ich występowania mogą wpływać na zmiany reżimu ekstremów termicznych. Trudno jednak stwierdzić, czy przyszłe zmiany częstości występowania wyżów blokujących doprowadzą do zmniejszenia się liczby ekstremów termicznych. Cyrkulacja atmosferyczna też bowiem zmienia się w następstwie antropogenicznie uwarunkowanych zmian w systemie klimatycznym Ziemi.

\section{Wnioski}

1. Dla porównywalności wyników studiów poświęconych ekstremom termicznym ważne jest przyjęcie podobnych kryteriów wydzielania. W studiach poświęconych występowaniu fal upałów w Europie Środkowo-Wschodniej można postulować trzymanie się definicji fal upałów jako co najmniej trzech dni z temperaturą 
maksymalną $>30,0^{\circ} \mathrm{C}$. W przypadku fal mrozów zaproponowanie ogólnie przyjmowanego kryterium wydzielania będzie trudne.

2. W całym badanym okresie w obniżeniach dolinnych Gór Świętokrzyskich wystąpiło kilkanaście fal upałów (najwięcej w Kielcach - 17) i 4-12 (zależnie od miejsca i przyjętego kryterium) fal mrozów.

3. Mimo niedużych wysokości względnych w Górach Świętokrzyskich występuje wyraźne wysokościowe zróżnicowanie liczby dni gorących i upalnych oraz nocy gorących i fal upałów. Na wierzchowinie Łysogór wystąpiło dwa razy mniej dni gorących niż na niżej położonych obszarach, a fale upałów były tam bardzo rzadkie. Najczęściej za to występowały tam noce gorące.

4. W przypadku dni bardzo mroźnych i fal mrozów wysokościowe zróżnicowanie ich liczby jest mniejsze.

5. Potencjalny okres występowania fal upałów jest prawie o 20 dni dłuższy niż fal mrozów.

6. W badanym okresie widoczny jest wyraźny wzrost liczby dni gorących i upalnych na wszystkich badanych stacjach meteorologicznych. Wyraźny wzrost liczby fal upałów zaznaczył się tylko w podkieleckim Sukowie. Spadek liczby dni bardzo mroźnych i fal mrozów jest słabo wyrażony, silniej zaznaczył się tylko na stacji meteorologicznej Kielce-Suków.

7. Zastosowane w pracy wskaźniki WSNC i WSNZ dobrze charakteryzują nasilenie, a zatem i uciążliwość fal upałów i fal mrozów.

\section{Literatura}

Batko A., Twardosz R., 2013, Fale upatów w Europie Środkowej na præetomie XX i XXI wieku, Acta Balneologica, 55, 4, 304-311.

Bielec-Bąkowska Z., 2014, Silna wyæ̇e nad Europq (1951-2010), Wydawnictwo Uniwersytetu Śląskiego, Katowice.

Black E., Blackburn M., Harrison G., Hoskins B., Methven J., 2004, Factors contributing to the summer 2003 European heatwave, Weather, 59, 8, 217-223.

Buczkowska H., Bednarek H., 2005, Ocena plonowania dwóch odmian papryki stodkiej w polu w odniesieniu do warunków termicznych, Acta Agrophysica, 4, 3, 567-575.

Dobrovolný P., Moberg A., Brázdil P., Pfister Ch., Glaser R., Wilson R., Van Engelen A., Limanówka D., Kiss A., Halíčková M., Macková J., Riemann D., Luterbacher J., Böhm R., 2011, Monthly, seasonal and annual temperature reconstructions for Central Europe derived from documentary evidence and instrumental records since AD 1500, Climate Change, 101, 1-2, 69-107.

Glossary of Meteorology, 2015, Cold wave, American Meteorological Society, http://glossary. ametsoc.org/wiki/cold wave (10.10.2015). 
Głowicki B., 2008, Ekstremalne zjawiska termiczne w Sudetach w okresie wspótczesnych zmian klimatu, Infrastruktura i Ekologia Terenów Wiejskich, 8, 29-40.

Guirguis K., Gershunov A., Schwartz R., Bennett S., 2011, Recent warm and cold daily winter temperature extremes in the Northern Hemisphere, Geophysical Research Letters, 38, 17, http:// onlinelibrary.wiley.com/doi/10.1029/2011GL048762/full (8.11.2015).

Hartmann D.L., Klein Tank A.M.G., Rusticucci M., Alexander L.V., Brönnimann S., Charabi Y., Dentener F.J., Dlugokencky E.J., Easterling D.R., Kaplan A., Soden B.J., Thorne P.W., Wild M., Zhai P.M., 2013, Observations: Atmosphere and Surface, [w:] T.F. Stocker, D. Qin, G.-K. Plattner, M. Tignor, S.K. Allen, J. Boschung, A. Nauels, Y. Xia, V. Bex, P.M. Midgley (red.), Climate Change 2013: The Physical Science Basis. Contribution of Working Group I to the Fifth Assessment Report of the Intergovernmental Panel on Climate Change, Cambridge University Press, Cambridge-New York, http://www.ncdc.noaa.gov (15.06.2015).

Huynen M.M.T.E., Martens P., Schram D., Weijenber M.P., Kunst A.E., 2001, The Impact of Heat Waves and Cold Spells on Mortality Rates in the Dutch Population, Environmental Health Perspectives, 109, 5, 463-470.

Kłysik K., 1974, Warunki termiczne obszaru swiętokrzyskiego, Zeszyty Naukowe Uniwersytetu Łódzkiego, Nauki Matematyczno-Przyrodnicze, Seria II, 63, 57-74.

Kossowska-Cezak U., 2010, Fale opatów $i$ okresy upalne - metody ich wyró:niania $i$ wyniki zastosowania, Prace Geograficzne, 123, 143-149.

Krzyżewska A., 2014, Præeglad metod wydzielania fal upatów i fal mrozów, Przegląd Geofizyczny, 59, 3-4, 257-174.

Krzyżewska A., 2015, Szczególnie uciqżliwe fale upatów w Lublinie, Przegląd Geofizyczny, 60, 3-4, 207-215.

Krzyżewska A., Wereski S., 2011, Fale upatów i mrozów w wybranych stacjach Polski na tle regionów bioklimatycznych (2000-2010), Przegląd Geofizyczny, 56, 1-2, 99-109.

Kuchcik M., 2006, Defining heat wave - different approaches, Geographia Polonica, 79, 2, 47-63.

Kyselý J., 2002, Temporal fluctuations in heat waves at Prague-Clementinum, the Ciech Republic, from 1901-1997, and their relationships to atmospheric circulation, International Journal of Climatology, 22, 33-50.

Kyselý J., Karlová J., Kvĕtoň V., 2000, Heat waves in the South Moravian Region during the period 1961-1995, Studia Geophysica et Geodaetica, 44, 57-72.

Kyselý J., Pokorna L., Kyncl J., Kriz B., 2009, Excess cardiovascular mortality associated with cold spells in the Ciech Republic, BMC Public Health, 9, 19, www.ncbi.nlm.nih.gov/ pubmed/19144206, doi: 10.1186/1471-2458-9-19 (9.11.2014).

Mann M.E., 2002, Little Ice Age, [w:] M.C. MacCracken, J.S. Perry (red.), Encyclopedia of Global Environmental Change., Vol. 1. The Earth system: Physical and chemical dimensions of global environmental change, John Wiley \& Sons Ltd., Chichester.

Mapa przegladowa Europy, Polska, 1989, skala 1:100 000, PPWK, Warszawa-Wrocław. 
Niedźwiedź T., Obrębska-Starklowa B., Olecki Z., 1973, Stosunki termiczno-wilgotnościowe wybranych zbiorowisk roślinnych w zachodniej części Świętokrzyskiego Parku Narodowego, Folia Geographica, Series Geographica-Physica, 8, 27-75.

Panfil M., 2005, Ekstrema termiczne w pótnocno-wschodniej Polsce w latach 1951-2000, Woda - Środowisko - Obszary wiejskie, 5, 237-242.

Piotrowicz K., 2005, Ekstremalne warunki termiczne w Krakowie, [w:] E. Bogdanowicz, U. Kossowska-Cezak, J. Szkutnicki (red.), Ekstremalne sjawiska hydrologiczne i meteorologiczne, PTGeof., IMGW, Warszawa, 89-96.

Prior J., Kendon M., 2011, The UK winter of 2009/2010 compared with severe winters of the last 100 years, Weather, 66, 1, 4-10.

Stownik meteorologiczny, red. T. Niedźwiedź, 2003, IMiGW, PTGeof., Seria: Atlasy i Monografie IMGW, Warszawa.

Rebetez M., Dupont O., Giroud M., 2008, An analysis of the July 2006 heatwave extent in Europe compared to the record year of 2003, Theoretical and Applied Climatology, 95, 1-2, 1-7.

Sillmann J., Croci-Maspioli M., 2009, Present and future atmospheric blocking and its impact on European mean and extreme climate, Geophysical Research Letters, 36, 10, http://onlinelibrary.wiley.com/doi/10.1029/2009GL038259/pdf (18.12.2015).

Tomczyk A.M., 2012, Pogoda upalna w Poznaniu w latach 1980-2011, Słupskie Studia Geograficzne, 6, 155-162.

Twardosz R., Kossowska-Cezak U., 2013, Exceptionally hot summers in Central and Eastern Europe (1951-2010), Theoretical and Applied Climatology, 112, 3-4, 617-628.

Wibig J., Podstaczyńska A., Rzepa M., Piotrowski P., 2009a, Colwaves in Poland - Frequency, Trends and Relationships with Atmospheric Circulation, Geographia Polonica, 82, 1, 47-59.

Wibig J., Podstaczyńska A., Rzepa M., Piotrowski P., 2009b, Heatwaves in Poland - Frequency, Trends and Relationships with Atmospheric Circulation, Geographia Polonica, 82, 1, 33-46.

Woś A., 2010, Klimat Polski w drugiej połowie XX wieku, Wydawnictwo Naukowe UAM, Poznań.

Krzysztof Jarzyna

Uniwersytet Jana Kochanowskiego w Kielcach

Instytut Geografii

ul. Świętokrzyska 15, 25-406 Kielce

e-mail:jarzynak@ujk.edu.pl 